\title{
The task of critique in times of post-truth politics
}

\author{
Sebastian Schindler ${ }^{\star}$ \\ Geschwister Scholl Institute of Political Science, Ludwig-Maximilians-Universität München, Germany \\ ${ }^{\star}$ Corresponding author. Email: sebastian.schindler@gsi.uni-muenchen.de
}

(Received 20 July 2018; revised 6 December 2019; accepted 16 December 2019; first published online 24 March 2020)

\begin{abstract}
Post-truth politics poses a specific problem for critical theories. The problem is that the relativisation of facts - the claim that knowledge is merely a product of power, history, and perspective - is a core aspect of present-day ideological thinking. Critical theories have been unable to respond to this challenge, because their critique has been directed against the opposite claim, namely the naturalisation of facts. While acknowledging this problem, this article argues that post-truth discourse actually combines relativisation and naturalisation. It does not simply relativise truth, but also naturalises the belief in specific 'facts' notably the belief that 'conspiracies are behind it all'. Once we recognise the twin character of posttruth, we must reject the view of Bruno Latour and others who have made critique responsible for the crisis. Instead, it then becomes apparent that there are deep and disconcerting similarities between post-truth politics and the totalitarian and authoritarian ideologies of the twentieth century. The task of critique is to confront and counter this resurgent ideology, thereby providing direction and orientation in the struggle for emancipation.
\end{abstract}

Keywords: Critique; Critical Theory; Conspiracy Theories; Emancipation; Ideology; Truth

\section{Introduction}

There is some confusion regarding the implications of recent political developments for the critical study of ideology, knowledge, and power. While critical research prides itself on its ability to question naturalised, taken-for-granted beliefs, its critique seems to have become commonplace. Even worse, it seems that populist and nationalist politicians - Donald Trump and his ilk - are quite comfortable with the basic premises of critique, and use it for their own purposes. It is the ideologues themselves who claim that there is an alternative to every fact and who criticise knowledge as constructed through power. In their view, it is the power of the 'mainstream' media that imposes a false, manipulative perspective on the world. The critique of ideology, it seems, has itself become a mainstay of contemporary articulations of ideology. Against this background, what is the task of critical inquiry today? Should its critique of truth claims become even more radical, further deconstructing critique itself? Or, conversely, is it necessary to retreat? Isn't the defence of truth the main task for critique in times of post-truth politics?

This article attempts to bring some clarity into this confusion. I will argue that the problem is not as new as it appears. The radical critique that knowledge is constructed through power was already an element of the authoritarian and totalitarian ideologies of the twentieth century. The problem is that many critical scholars have focused narrowly on questioning the naturalisation of facts, failing to acknowledge that the relativisation of facts is equally a feature of ideological thinking. Critical theories have tended to construct a binary distinction between

(C) The Author(s) 2020. This is an Open Access article, distributed under the terms of the Creative Commons Attribution-NonCommercialNoDerivatives licence (http://creativecommons.org/licenses/by-nc-nd/4.0/), which permits non-commercial re-use, distribution, and reproduction in any medium, provided the original work is unaltered and is properly cited. The written permission of Cambridge University Press must be obtained for commercial re-use or in order to create a derivative work. 
ideology-as-naturalisation and theory-as-relativisation. Against the background of this binary distinction, it has appeared as though the advancement of critique is equivalent to the destruction of more and more naturalised facts. However, as I will argue, this binary distinction is misleading. It has misled critical researchers into thinking that their task consists in a continuous radicalisation of (relativising) critique. Contradicting this trend, I will argue that the task of critique is to problematise two defects: uncritical belief in truth claims, on the one hand, and the uncritical relativisation of all truth claims, on the other. Both extremes, naïve belief and cynical disbelief, are forms of ideology.

In recent years, several critical scholars in and beyond the discipline of International Relations (IR) have articulated concerns about the state of critical theory and the adequacy of the predominant strategies of critique. ${ }^{1}$ One core concern of many critics has been that the emphasis on context, discourse, and history has led to the neglect of factors such as reality, totality, and truth. ${ }^{2} \mathrm{My}$ key move in this article will be to apply this point to the critique of ideology. All critical thinking hinges on a concept of ideology. ${ }^{3}$ It hinges on a distinction between right and wrong, between critique and dogmatism, between theory and ideology. In many current critical theories, this distinction is implicit rather than explicit. Yet it is there nonetheless. There is always a certain kind of knowledge (traditional, mainstream, colonial, essentialising, etc.) that is criticised and another kind of knowledge (reflexive, non-totalitarian, non-violent, de-essentialising, etc.) that is sought and defended. ${ }^{4}$ While the distinction between theory and ideology is today usually cast as one between relativisation and naturalisation, the post-truth phenomenon has made it abundantly clear that this binary needs to be problematised. The claim that knowledge is 'entirely' independent from history, power, and perspective (that is, 'naturalisation' as I understand the term in this article) is as implausible as its opposite - the claim that knowledge is 'merely' the product of history, power, and perspective ('relativisation'). ${ }^{5}$ True knowledge is never 'purely' objective or 'merely' subjective, but always both at the same time.

\footnotetext{
${ }^{1}$ Milja Kurki, 'The limitations of the critical edge: Reflections on critical and philosophical IR scholarship today', Millennium, 40:1 (2011), pp. 129-46; Albena Azmanova, 'Crisis? Capitalism is doing very well: How is critical theory?', Constellations, 21:3 (2014), pp. 351-65; Felix Anderl and Philip Wallmeier, 'Modi der Kritik des internationalen Regierens: Ein Plädoyer für immanente Kritik', Zeitschrift für Internationale Beziehungen, 25:1 (2018), pp. 65-89.

${ }^{2}$ Matthew Fluck, 'Truth, values and the value of truth in critical International Relations theory', Millennium, 39:2 (2010), pp. 259-78; Matthew Fluck, 'The best there is? Communication, objectivity and the future of critical International Relations theory', European Journal of International Relations, 20:1 (2014), pp. 56-79; Inanna Hamati-Ataya, 'Reflectivity, reflexivity, reflexivism: IR's "reflexive turn” - and beyond', European Journal of International Relations, 19:4 (2013), pp. 669-94; Kai Koddenbrock, 'Strategies of critique in IR: From Foucault and Latour towards Marx', European Journal of International Relations, 21:2 (2015), pp. 243-66; Pol Bargués-Pedreny, 'Connolly and the never-ending critiques of liberal peace: From the privilege of difference to vorarephilia', Cambridge Review of International Affairs, 30:2 (2017), pp. 216-34; Kjersti Lohne, 'As the universal breaks', New Perspectives, 26:3 (2018), pp. 135-42; Davide Schmid, 'The poverty of critical theory in International Relations: Habermas, Linklater and the failings of cosmopolitan critique', European Journal of International Relations, 24:1 (2017), pp. 198-220.

${ }^{3}$ Raymond Geuss, The Idea of a Critical Theory: Habermas and the Frankfurt School (Cambridge: Cambridge University Press, 1981).

${ }^{4}$ This is very clear for instance in Steve Smith, 'Singing our world into existence: International Relations theory and September 11', International Studies Quarterly, 48:3 (2004), pp. 499-515.

${ }^{5}$ Naturalisation is a term common to many critical theories, in particular of feminist and postcolonial varieties - it means seeing as natural 'that which is [in reality] historically produced'. Sanja Seth, 'Postcolonial theory and the critique of International Relations', Millennium, 40:1 (2011), p. 168. The corresponding term in Marxist theories is 'reification', a concept central also to constructivist theory. Alexander Wendt, 'Anarchy is what states make of it: The social construction of power politics', International Organization, 46:2 (1992), p. 410. In contrast, a perspective that sees all knowledge as purely historical is commonly termed 'relativist' - hence my expression 'relativisation'. Relativisation involves an exclusive reliance on 'historicisation', that is, in the words of Matthew Fluck, 'one of the simplest but most effective strategies of reflexive IR [...] which serves to denaturalise and contextualise'. Matthew Fluck, 'Theory, "truthers", and transparency: Reflecting on knowledge in the twenty-first century', Review of International Studies, 42 (2016), p. 55. My use of such terms as 'merely', 'entirely', or 'purely' is intended to express the excessive, ideological character of both naturalisation and relativisation.
} 
The critique of the naturalisation/relativisation binary is not purely an academic and theoretical enterprise. It is practically and politically necessary. Prominent theorists such as, notably, Bruno Latour recognised very early on that there is a problem with the currently predominant strategies of critique. Critique has run 'out of steam', Latour claimed in an important article, because it is complicit in relativising facts and therefore unable to confront the politically virulent scepticism of facts such as climate change or evolution. ${ }^{6}$ However, Latour is correct only to the extent that the prevalent understanding of ideology is indeed narrowly focused on the problem of naturalisation. Contra Latour and many other observers who have pointed the finger at critical theories of knowledge, I argue that critique is not responsible for the crisis. There are deep and disconcerting similarities between post-truth politics and earlier ideologies from the twentieth century. Like these earlier ideologies, the post-truth discourse combines relativisation and naturalisation. It does not simply relativise truth, but also naturalises the belief in specific 'facts', notably the belief that 'conspiracies are behind it all' - for instance, behind the scientific consensus on the fact of climate change. The task of critique is to confront and counter this ideology, thereby providing direction and orientation in the struggle for emancipation.

My article proceeds in five steps. In the first section, I will uncover the role of the naturalisation/ relativisation binary in a seminal article by early critical IR theorist Robert Cox. Then, in the second section, I will unveil the radicalising dynamic inherent in this binary, before going on to argue in the third section that relativisation is a crucial political problem in our time. Fourth, I will show that both relativisation and naturalisation were features of twentieth-century ideologies. In the fifth and final section, I will spell out the task of critique in contemporary times.

\section{Critique of ideology as critique of naturalisation}

Robert Cox's article 'Social Forces, States and World Orders: Beyond International Relations Theory' has become a seminal point of reference in critical IR scholarship. ${ }^{7}$ Cox introduced into IR a distinction that is articulated also in a classical work of the Critical Theory of the Frankfurt School. ${ }^{8}$ In Cox's rendering, Max Horkheimer's distinction between 'traditional and critical theory' became one between 'problem-solving and critical theory', but Cox unknowingly rearticulates some of Horkheimer's insights. ${ }^{9}$ Cox's article helped to open a space for critical theorising in IR. A special issue in the Review of International Studies dedicated to 'Critical International Relations Theory after 25 years' introduced Cox's article, together with an equally renowned piece by Richard Ashley, as the beginning of critical IR. ${ }^{10}$ Indeed, Cox argued that there are two different kinds of theories and that IR had hitherto privileged the one at the price of neglecting the other. ${ }^{11}$

The distinction between problem-solving and critical theory depends, for Cox, on how a theory relates to its enmeshment in historical structures and conditions. According to Cox, all theories view the world from a specific standpoint. These standpoints can be defined in a variety of

\footnotetext{
${ }^{6}$ Bruno Latour, 'Why has critique run out of steam? From matters of fact to matters of concern', Critical Inquiry, 30 (winter 2004), pp. 225-48.

${ }^{7}$ Robert Cox, 'Social forces, states and world orders: Beyond International Relations theory', Millennium, 10:2 (1981), pp. 126-55.

${ }^{8}$ Max Horkheimer, 'Traditional and critical theory', in Critical Theory: Selected Essays, trans. Matthew J. O'Connell et al. (New York: Continuum, 2002), pp. 188-243.

${ }^{9}$ Beate Jahn, 'One step forward, two steps back: Critical theory as the latest edition of liberal idealism', Millennium, 27:3 (1998), pp. 616-17.

${ }^{10}$ Nicholas Rengger and Ben Thirkell-White, 'Still critical after all these years? The past, present and future of critical theory in International Relations', Review of International Studies, 33:S1 (2007), pp. 3-24.

${ }^{11}$ Similarly, Ashley used Habermas's distinction between three 'knowledge-constitutive interests' (Erkenntnisinteressen) to argue that a specific kind of critically minded research - research with an emancipatory interest - had hitherto played a subordinate role in IR theory. Unlike Cox, Ashley sought this emancipatory, critical research interest within rather than outside of the dominant realist theory, and discovered this critical spirit notably in aspects of the work of John Herz. Richard Ashley, 'Political realism and human interests', International Studies Quarterly, 25:2 (1981), pp. 204-36.
} 
ways, for instance in terms of 'nation or social class, of dominance or subordination, of rising or declining power, of a sense of immobility or of present crisis, of past experience, and of hopes and expectations for the future'. ${ }^{12}$ Cox asserts that there is 'no such thing as theory in itself, divorced from a standpoint in time and space'. ${ }^{13}$ But there are theories that pretend to have access to an ahistorical standpoint, and 'when any theory so represents itself, it is the more important to examine it as ideology, and to lay bare its concealed perspective'. ${ }^{14}$ Theory is ideological to the extent that it conceals its perspective and claims to have access to universal truth.

Cox maintains that theories that do not reflect on their perspective - theories that are, in this sense, ideological - may still be good at solving the problems that arise within a particular order. They are 'problem-solving' theories that accept the given parameters and take the world as they find it. ${ }^{15}$ However, problem-solving theory lacks reflexivity. It is oblivious of its own nature in the sense that it doesn't know the historical origins and the uses of the conceptions on which it relies. Conversely, critical theory

stands apart from the prevailing order of the world and asks how that order came about. Critical theory, unlike problem-solving theory, does not take institutions and social and power relations for granted but calls them into question by concerning itself with their origins and how and whether they might be in the process of changing. It is directed towards an appraisal of the very framework for action, or problematic, which problem-solving theory accepts as its parameters. ${ }^{16}$

While problem-solving theory accepts the prevailing order of the world as it is, critical theory examines the origins of this order and the changes it undergoes. While problem-solving theory conceals its own perspective, critical theory reflects upon it.

These distinctions between problem-solving and critical theory are binary distinctions. They accord a specific task to critical theory, namely that of unveiling the contingency, historicity, and relativity of the perspective that uncritical theory (or theory-as-ideology) takes for granted. Problem-solving theory conceals its perspective by claiming that its worldview is universal and ahistorical. In contrast, critical theory reveals that theoretical claims are linked to standpoints, and thus unveils the ideological character of problem-solving theory. Ultimately, critical theory demonstrates that problem-solving theory is founded upon a 'false premise': the premise of the fixity of social order. ${ }^{17}$ This fixity is 'not merely a convenience of method, but also an ideological bias'. ${ }^{18}$ By taking for granted a specific order, problem-solving theory ultimately serves 'particular national, sectional, or class interests, which are comfortable within the given order'. ${ }^{19}$

Cox's distinction between problem-solving and critical theory is founded on a binary of two thought operations: naturalisation (that conceals) and relativisation (that unveils). Yet as heavily as Cox relies on this binary, he still does not follow it through completely. In fact, critical theory, according to Cox, is also characterised by a move beyond mere relativism. Thus he argues that 'the more sophisticated a theory is, the more it reflects upon and transcends its own perspective'. ${ }^{20}$ Transcendence is a core virtue of critical theory in Cox's sense. ${ }^{21}$ Critical theory becomes 'clearly

\footnotetext{
${ }^{12} \mathrm{Cox}$, 'Social forces, states and world orders', p. 128.

${ }^{13} \mathrm{Ibid}$

${ }^{14}$ Ibid.

${ }^{15}$ Ibid.

${ }^{16}$ Ibid., p. 129.

${ }^{17}$ Ibid.

${ }^{18}$ Ibid.

${ }^{19}$ Ibid.

${ }^{20}$ Ibid.

${ }^{21}$ In fact, Robert Cox is not known today in the IR discipline as a proponent of relativisation. Rather to the contrary, his take on critical theory has become associated with a version of critical theory that takes too much for granted. This point was
} 
aware of the perspective which gives rise to theorizing, and its relation to other perspectives' ${ }^{22}$ It achieves a 'perspective on perspectives'. ${ }^{23}$ But even though it transcends its own perspective, critical theory remains bound to a particular perspective, both in the sense that its original perspective remains contained in it, and in the sense that it is a perspective on perspectives.

Critical theory is two things in one: it is both a particular perspective and a perspective that transcends perspectives, a perspective that is more than merely the view of all others, but instead a standpoint that transcends the others precisely by having recognised them and still having maintained its own standpoint. ${ }^{24}$ Here, the binary of ideology-as-naturalisation and theory-asrelativisation reaches a limit. It becomes obvious that critical theory does not merely unveil perspectivity, but itself claims to access a perspective that is more than a mere perspective, more than a mere standpoint in time and space. Thus, critical theory not only demonstrates the relativity of all standpoints, but also strives for objectivity, in the sense of moving beyond the relativity of its own standpoint to achieve a perspective on perspectives. As Cox himself formulates this paradox, 'critical theory is conscious of its own relativity but through this consciousness can achieve a broader time-perspective and become less relative than problem-solving theory'. ${ }^{25}$ Critical theory is both more relative and less relative than problem-solving theory: more relative since it doesn't openly claim universality, and at the same time less relative, since, by means of this renunciation, it actually accesses a transcendent point beyond merely relative standpoints.

Cox's privileging of relativisation over naturalisation is not free of ambiguity. While Cox clearly ascribes to critical theory the task of relativising that which problem-solving theory naturalises, he nonetheless argues that in this manner a less relative perspective is achieved - in other words, a perspective that is in some way more than a mere standpoint in space and time, namely a 'perspective on perspectives'. Critical theory is characterised not only by its acknowledgement of the historicity of knowledge, but also by a move beyond historicity towards objectivity. However, while Cox acknowledges this basic point, he - in common with many thinkers who followed him - has not applied it to the critique of ideology. Cox and his followers have continued to criticise naturalisation alone, but have failed to extend their critique to relativisation as well. It is this omission that has rendered critique increasingly radical, triggering an escalatory dynamic implicit in the naturalisation/relativisation binary.

\section{The radicalisation of critique}

Critical IR has become such a large and diverse field of research that its development cannot be reduced to a single tendency. Instead of attempting to offer an overview of this diversity, I will focus on what its proponents have written about its history. For this purpose, the abovementioned special issue of the Review of International Studies to mark the twenty-fifth

\footnotetext{
already advanced by Nick Rengger in the so-called inter-paradigm debate. Rengger criticised Mark Hoffman's summary statement of Critical Theory (CT) as only one specific kind of such a theory (namely 'Coxian Critical Theory' - CCT), since important critical theorists such as Rorty and Foucault had a far more radical perspective on the question of historicity of knowledge in particular. This more radical perspective has, Rengger claimed, 'the awkward corollary that all our conceptions may simply be historically contingent, that there is, in other words, nothing that is "universal to world order" because there is nothing that is universal at all'. Nick Rengger, 'Going critical? A response to Hoffman', Millennium, 17:1 (1988), pp. 85-6; Mark Hoffman, 'Critical theory and the inter-paradigm debate', Millennium, 16:2 (1987), pp. 231-49. However, while Rorty explicitly embraced the term 'relativism', Foucault's thought at least offers resources for a non-relativising form of critique as well. Through the engagement with our own history, Foucault's (and Nietzsche's) genealogies enable us to access a knowledge about ourselves that transcends, one could say, this very history. Martin Saar, Genealogie als Kritik: Geschichte und Theorie des Subjekts nach Nietzsche und Foucault (Frankfurt am Main: Campus, 2007).

${ }^{22} \mathrm{Cox}$, 'Social forces, states and world orders, p. 128.

${ }^{23}$ Ibid.

${ }^{24}$ As Hamati-Ataya puts it, critical theory according to Cox is 'both inside and outside of itself, both subject and object of knowledge'. Hamati-Ataya, 'Reflectivity, reflexivity, reflexivism', p. 675.

${ }^{25}$ Cox, 'Social forces, states and world orders', p. 135.
} 
anniversary of critical IR provides an ideal starting point. The contributors were explicitly asked to reflect on the history of critical research in IR during the 25 years since the publication of Cox's and Ashley's articles in $1981 .^{26}$ Their responses were, of course, different. Yet there was broad agreement that, while Cox and Ashley provided an important impetus, the field had moved on and transcended the original critical project, at least in part. But in what sense can the field be said to have moved on? I will analyse in detail the answer provided by one contributor in particular, Kimberly Hutchings. ${ }^{27}$

In her analysis of the development of critical thinking in IR since Cox, Hutchings focuses on concepts of time and progress. Her article identifies three stages in this development. The first stage is the time of Cox and Ashley, who according to Hutchings had a specifically Western conception of time. Cox's and Ashley's conception of time was based on two different notions, one being clock time (a linear, inevitable progression of time), the other calendar time (the idea that a new, revolutionary beginning can be made; progress is possible). These two conceptions of time, Hutchings claims, are not as universal as they may appear. They presuppose a 'single, progressive temporality' and thereby end up reproducing and confirming 'the hegemonic pattern of international power', rather than, as Ashley and Cox pretend, 'challenging' it. $^{28}$ In other words, according to Hutchings, the first stage of critical thinking in IR disguises a particular perspective in the garb of universality. Ashley and Cox do precisely what Cox ascribed to problem-solving theory: they take for granted a particular perspective on the world, or more precisely, on temporality. According to Hutchings, Cox and Ashley formulate ideological rather than critical theories. As Hutchings affirms, this makes their assumptions not only unwarranted, but also dangerous: 'dangerous because they distract attention from political plurality, and thereby risk repeating the hubris of Western political imaginaries'. ${ }^{29}$

While postmodern and poststructuralist critics of Cox and Ashley recognised the limitations of the latters' particular perspectives on temporality, according to Hutchings they did not fully unfold the critical project either. Postmoderns and poststructuralists did manage to dissolve and overcome the idea that there is a linear relationship between past and future inherent in the Marxian and Gramscian thought of Cox and Ashley: 'Both kinds of critical theory stress the openness and indeterminacy of the future. ${ }^{30}$ But while postmodernism and poststructuralism shattered the idea of 'potentially progressive and universalizing forces of history', presupposed by Cox and Ashley, their transcendence of the early critical thinkers may, as Hutchings writes, 'not be as radical and complete as it appears'. ${ }^{31}$ In fact, as Hutchings goes on to demonstrate, the poststructuralists and postmodernists also naturalise a particular, Western perspective on temporality. Derrida's 'ethical orientation', for instance, 'is specific to a particular ethical and political tradition, which is given a universal pertinence'. ${ }^{32}$ According to Hutchings, Derrida conceals the fact that his own perspective on temporality is only one among many possible perspectives, and thereby formulates an ideological theory, not a truly critical one. The concealed perspective of Derrida and other postmodern thinkers can be revealed by taking into account a further stage of critical thinking, namely feminist and postcolonial theory.

\footnotetext{
${ }^{26}$ Rengger and Thirkell-White, 'Still critical after all these years?'.

${ }^{27}$ Kimberly Hutchings, 'Happy anniversary! Time and critique in International Relations theory', Review of International Studies, 33:S1 (2007), pp. 71-89. In the same issue, John Hobson adopts a perspective that is in many respects similar to that of Hutchings: John Hobson, 'Is critical theory always for the white West and for Western imperialism? Beyond Westphilian towards a post-racist critical IR', Review of International Studies, 33:S1 (2007), pp. 91-116. Here I will focus on Hutchings's reflections, because they enable me to develop a systematic argument about the impact of the naturalisation/relativisation binary on the development of critical thinking.

${ }^{28}$ Hutchings, 'Happy anniversary!', p. 72.

${ }^{29}$ Ibid., p. 89.

${ }^{30}$ Ibid., p. 81 .

${ }^{31}$ Ibid.

${ }^{32}$ Ibid., p. 83.
} 
Hutchings's critique of the two early stages of critical IR theory - Marxian/Gramscian, and postmodern/poststructuralist - has the merit of bringing to the fore deeper assumptions on which these early critical thinkers rely and which they take for granted. It is not possible to engage with the full scope of Hutchings's critique in the present context. However, what I have said makes clear that Hutchings also relies on a particular notion of progress in critical thinking, namely, that progress involves increasing relativisation. Hutchings presents each stage of critical thinking as marking an advance over the previous stage in that it reveals the concealed perspectives of the earlier thinkers. Thus, the postmoderns and poststructuralists unveil the concealed perspective of Cox and Ashley's critical theories, while feminists and postcolonial thinkers uncover the concealed perspective of the postmoderns and poststructuralists. On each occasion, the critical posture of the earlier critics is shown to be only seemingly critical of universality, but instead to be enmeshed in the reproduction of a particularistic Western identity and, hence, complicit in international hegemonic power rather than critical of it. At each stage, critique is shown to be insufficiently radical, to be not 'historical enough". ${ }^{33}$ But in the end, the basic insight is still the one formulated by Cox, namely the unveiling of a 'concealed perspective'. ${ }^{34}$

Hutchings not only articulates a particular perspective on the meaning of progress in critical thinking, one that is not rendered explicit and thus itself criticisable as concealed. She also adheres to the core of Cox's own definition of critical theory, which consists precisely in the unveiling of concealed perspectives (or, in other words, in the 'relativisation' of the seemingly natural, universal, and rational). In this way, the advancement of critical thinking is given a particular, limited meaning and temporal unidirectionality. Hutchings rightly emphasises that the avant-garde of progress - in her eyes, postcolonial theory as well as feminism - finds itself very much in a minority position, a position of marginalisation. Still, one wonders where precisely this minority is heading given that its direction had been, if we follow Hutchings's own account, clear from the outset, namely towards more and more relativisation, and thus following precisely the route set out by the binary distinction between ideology-as-naturalisation and theory-as-relativisation. But where do we end up if we follow this route to the end? Is an end even conceivable? Are there not certain risks inherent in the continuous radicalisation of critique?

The point here is not to associate entire theories solely with a radicalised form of relativising critique. It is only to show that the naturalisation/relativisation binary tends to move the critical project in a certain direction. This binary entails a logic of progress that drives critical thinking towards 'pure' or 'mere' relativisation and thereby actually risks making critique itself uncritical. Now the truth is, of course, that none of the streams of critical thinking discussed in summarising form by Hutchings can be reduced to an exercise in relativisation. Jacques Derrida, to take a prominent example, was concerned not only about destruction but also construction. While Derrida repeatedly inquired into what is ignored or left out by certain theoretical approaches, he nonetheless sought to construct a more complete account of practice. Revealing the limits, for instance, of John Austin's speech act theory or of Foucault's account of madness and reason, Derrida argued for a more comprehensive view of speech or of the relationship between madness and reason. ${ }^{35}$ Derrida's relativisation of earlier theories aimed, in this sense, at a more universal and more objective theory. ${ }^{36}$ And also in the theories that for Hutchings are situated at the leading edge of contemporary critical theorising in IR - postcolonial and feminist approaches - one, of course, finds a concern for more inclusive and, in this sense, more universal practices. Hutchings herself emphasises this concern, and in the final section of her article cautions against both the idea of a 'singular master narrative of history' as well as a purely 'formal ethical

\footnotetext{
${ }^{33}$ Ibid., p. 78.

${ }^{34} \mathrm{Cox}$, 'Social forces, states and world orders', p. 128.

${ }^{35}$ Jacques Derrida, 'Différance', in Alan Bass (ed.), Margins of Philosophy (Chicago: University of Chicago Press, 1982), pp. 3-27; Jacques Derrida, Writing and Difference (Chicago: The University of Chicago Press, 1978), ch. 2.

${ }^{36}$ Norman Geras, 'The view from everywhere', Review of International Studies, 25:1 (1999), pp. 157-63.
} 
commitment to a mysterious "difference". ${ }^{37}$ Instead she emphasises the importance of 'double thinking' when it comes to time - a thinking that has a place for both 'being' and 'becoming', for both 'relatively stable contexts for political judgement and action' and 'shifting and unfamiliar contexts'. ${ }^{38}$ Hutchings discusses several thinkers who have sought to accord a place to both the 'systemic' and the 'pluralist' aspect of time - Chakrabarty, Connolly, and Deleuze - relying on different concepts such as History 1 and History 2, chronos and aion, machine and desire. ${ }^{39}$ However, the route of progress of critical thinking she charts is nonetheless marked by criticism, not of the pluralist, but only of the systemic aspect of time, which is alone associated with power and, in this sense, treated as the only ideology in town. Hutchings fails to apply 'double thinking' to the critique of ideology.

While the concern for more inclusive and more ethically sensitive practices is widely shared in critical IR scholarship, it is all too often translated into a generalised criticism of any claim to truth. All too often it appears as though more sensitive and reflective practices could only be had if one renounced entirely the use of concepts such as universality, reality, or objectivity. ${ }^{40}$ This problem has been recognised by several critical IR theorists who have sought to strike a new balance in critical thinking between the demand for reflexivity and the pursuit of truth. They have cautioned that reflexivity is too often automatically associated with a negative stance towards claims to truth, that critique must emphasise not merely historical contingency but also 'concrete totality', not merely difference but also universality, not merely the subjective but also the objective. ${ }^{41}$ And indeed, as Bruno Latour recognised as early as 2004, the concern about the radicalisation of relativising critique is not merely of academic interest.

\section{Critique out of steam? Relativisation as ideology}

In 2004, 12 years before Donald Trump's election as president of the United States, Bruno Latour published a self-critical article in which he cautioned against the continuous radicalisation of critique. Latour was troubled by the considerable success with which so-called 'climate sceptics' used critical arguments to raise doubts about the facticity of anthropogenic climate change. Having himself 'spent some time in the past trying to show "the lack of scientific certainty" inherent in the construction of facts', he wondered what it meant that this was precisely the point used by Republican members of the U.S. Congress in their attempt to dismantle the evidence assembled by climate scientists. ${ }^{42} \mathrm{He}$ had wanted to 'emancipate the public from prematurely naturalized objectified facts', but now it seemed as though the problem was of a quite different kind:

\footnotetext{
${ }^{37}$ Hutchings, 'Happy anniversary!', p. 88.

${ }^{38}$ Ibid., pp. 89,85 .

${ }^{39}$ Ibid., pp. $85-8$.

${ }^{40}$ In the words of Fluck, 'the underlying assumption of much critical IR scholarship has been that the theoretical concern with and practical orientation towards objectivity is in some sense inherently opposed to non-instrumental political practice'. Indeed, 'the very notion "object" has almost entirely negative connotations, having been seen as at best naïve but very often as complicit in social domination'. Fluck, 'The best there is?', pp. 63, 62. For notable examples of this phenomenon, see Claudia Aradau and Jef Huysmans, 'Assembling credibility: Knowledge, method and critique in times of "post-truth"', Security Dialogue, 50:1 (2019), pp. 44-6; Claudia Aradau and Jef Huysmans, 'Critical methods in International Relations: The politics of techniques, devices and acts', European Journal of International Relations, 20:3 (2014), pp. 596-619. Aradau and Huysmans introduce an understanding of critical methods according to which the latter always serve to disrupt extant worlds and establish alternative ones; yet it remains unclear whether and in which sense one could say that the alternative world is more objective or closer to the truth than the extant one. However, the articulation of alternatives inevitably relates to our current knowledge. It cannot help but transcend the latter. This applies, for instance, to critical historical methods that, by means of engaging with past alternatives, allow us to 'gain a more historically accurate sense of the present'. Richard Devetak, “The battle is all there is": Philosophy and history in International Relations theory', International Relations, 31:3 (2017), p. 274.

${ }^{41}$ Hamati-Ataya, 'Reflectivity, reflexivity, reflexivism', p. 684; Koddenbrock, 'Strategies of critique in IR'; Schmid, 'The poverty of critical theory in International Relations'; Azmanova, 'Crisis?'; Fluck, 'The best there is?'; Bargues-Pedreny, 'Connolly and the never-ending critiques of liberal peace'; Lohne, 'As the universal breaks'.

${ }^{42}$ Latour, 'Why has critique run out of steam?', p. 227, emphasis in original.
} 
The danger would no longer be coming from an excessive confidence in ideological arguments posturing as matters of fact - as we have learnt to combat so efficiently in the past - but from an excessive distrust of good matters of fact disguised as bad ideological biases! $!^{43}$

In other words, the danger was not coming from the uncritical belief in naturalised, objectified facts, but on the contrary, from the excessive disbelief in such facts, which undermined trust in 'good' facts that Latour had not wanted to relativise. Latour noticed this excessive distrust not only in statements by right-wing politicians and industrialists who wanted to further their own agenda, but also among the common rural population, the inhabitants of the village in which he lived, who ceased to trust the university professor: 'I am now the one who naïvely believes in some facts because I am educated, while the other guys are too unsophisticated to be gullible: "Where have you been? Don't you know that the Mossad and the CIA did it?" 44

Twelve years before the election of Donald Trump, therefore, Latour perceptively noticed some of the changes that had been unfolding not only among some irrelevant fanatics, but also among a wider spectrum of the population. Right-wing and populist movements draw considerable support especially from the countryside, where many people feel excluded and distrust not only specific politicians, but the political, liberal, journalistic, and academic elites in general. ${ }^{45}$ This exclusion, which is arguably both perceived and real, is one of the principal reasons for the rise of Trump and populist movements elsewhere. ${ }^{46}$ What Latour noticed was a change in the predominant way of dealing with matters of fact. Excessive distrust of (specific) facts had begun to become increasingly widespread, and it is this distrust that reminded Latour of the very distrust he himself had articulated, as theorist and researcher, towards truth claims.

Latour's perception of an increase in scepticism concerning the validity of facts is widely shared today. The term 'post-truth' and its twin notion 'post-factual politics' capture this perception well. The expression 'post-truth' became widespread in the context of the Brexit referendum and the election of Trump, both of which occurred in 2016. In the same year, post-truth was chosen as 'word of the year' by Oxford Dictionaries. ${ }^{47}$ According to Oxford Dictionaries, the term denotes 'circumstances in which objective facts are less influential in shaping public opinion than appeals to emotion and personal belief, and it was first used with the explicit meaning that 'truth itself has become irrelevant' in an essay by Steve Tesich published in the Washington Post in 1992. ${ }^{48}$ Indeed, as I will illustrate in the following with three more or less famous examples, Trump and his supporters have expressed a radicalised distrust of facts. They have not only questioned the validity of specific facts, explaining them as the result of conspiracies, but have adopted an attitude according to which truth in general has no value in public political debates.

Trump has made no secret of his denial of anthropogenic climate change. In November 2012, he shared on Twitter his view that climate change was a hoax: 'The concept of global warming was created by and for the Chinese in order to make U.S. manufacturing non-competitive', Trump tweeted. ${ }^{49}$ His message was well received. It was retweeted over 104,000 times, and

\footnotetext{
${ }^{43}$ Ibid., emphasis in original.

${ }^{44}$ Ibid., p. 228, emphasis in original.

${ }^{45}$ Arlie Russel Hochschild, Strangers in Their Own Land: Anger and Mourning on the American Right (New York: The New Press, 2016); Katherine Cramer, The Politics of Resentment: Rural Consciousness in Wisconsin and the Rise of Scott Walker (Chicago: The University of Chicago Press, 2016).

${ }^{46}$ For the case of France, see Didier Eribon, Returning to Reims (London: Penguin Books, 2016). For the case of the UK, see Hannah Marshall and Alena Drieschova, 'Post-truth politics in the UK's Brexit referendum', New Perspectives, 26:3 (2018), pp. 96-9.

${ }^{47}$ Alison Flood, “Post-truth” named word of the year by Oxford Dictionaries', The Guardian (15 November 2016).

${ }^{48}$ Quoted in ibid.

${ }^{49}$ \{https://twitter.com/realdonaldtrump/status/265895292191248385\} accessed 6 December 2017.
} 
'liked' over 66,000 times. ${ }^{50}$ What is interesting about Trump's tweet is not only its denial of the reality of anthropogenic climate change, a denial that became widespread among supporters of the political right in the United States long before Trump's political rise. What is interesting is how the 'creation' of this scientific fact is explained by Trump, namely, as a result of the selfish manoeuvrings of a specific agent. 'The Chinese', Trump alleges, created the concept of climate change in order to harm US manufacturing and further their competitive advantage. The existence of a fact is thus explained by the self-serving perspective of a particular actor; a claim to knowledge is relativised by unveiling Chinese interests behind it. This is arguably a very crude version of relativisation, but it is a form of relativisation nonetheless.

The debate over the participation at Trump's inauguration as US president in January 2017 provides another emblematic example of post-truth politics. In the course of this debate, Trump's senior adviser Kellyanne Conway coined the term 'alternative facts' in order to defend the claim that the ceremony had been attended by 'the largest audience to ever witness an inauguration', despite the publication of photos in The New York Times that proved this claim to be a lie. ${ }^{51}$ But Conway insisted nonetheless that the lie was no lie, but that it represented merely an alternative vision of reality. She didn't say that the presence of the 'largest audience' was a fact and that the deniers were liars. Instead, she claimed that the statement was an alternative fact. In other words, the acknowledgement of this fact depended, for her, merely on the perspective one took, on the particular stance one had on the issue. The notion of 'alternative facts' implies a generalised disbelief in the very possibility of facts. If facts have alternatives, then they are arguably not facts any more, but bones of contention, depending on the perspective one takes, on the standpoint one has. 'There is always an alternative fact' - such a cynical attitude, which transpires through Conway's statement, in fact implies that there are no facts at all. It implies that there is no distinction between fact and lie, but instead only a distinction between different half-truths. 'Truth is always relative' - this thesis encompasses the deeper meaning of what Conway said.

A third, less well-known illustration of Trumpian post-factual politics can be derived from an article that appeared in The New Yorker in March 2017. In this article, Andrew Marantz reports on how the entry of a right-wing blog from the American Midwest, the Gateway Pundit, transformed the White House Press corps. Marantz describes numerous irritating encounters between the reporter of the Gateway Pundit and established journalists. Particularly telling is, however, an episode described towards the end of Marantz's article. When Marantz informed the blog's representative, Jim Hoft, that The New Yorker's fact-checking team would soon be contacting him to confirm the facts of the reported story, Hoft responded with a joke. He claimed that his blog, the Gateway Pundit, had 'a huge department of full-time fact-checkers', too. Then he exploded in laughter 'so hard that he nearly spilled his lemonade'. ${ }^{2}$ In other words, Hoft didn't even try to disguise that he was uninterested in checking the facts. Instead, his joke implies that anyone who (still) believes in the boundary between fact and lie is just naïve. Also for Hoft (as for Conway), the very notion of a 'fact' has lost its meaning, at least as long as political interaction between opposing media factions is concerned. There is, for him, simply no truth behind anything, and thus everything can be constructed in this way or another, no matter whether one undertakes the work of fact-checking or not.

In the described three examples, Trump and his supporters act as if there is simply no boundary between truth and lie. They treat truth in general as relative. Latour's diagnosis of 2004 was foresighted and perceptive: it is not only naturalisation, but also relativisation that is a crucial political problem. However, Latour is wrong on another count. According to Latour and many other observers, the contemporary proliferation of relativising critique is an entirely new phenomenon. Latour suggests that conspiracy theories are 'an absurd deformation of our own [critical]

\footnotetext{
${ }^{50}$ Ibid.

${ }^{51}$ \{http://edition.cnn.com/2017/01/22/politics/kellyanne-conway-alternative-facts\} accessed 6 December 2017.

${ }^{52}$ Andrew Marantz, 'Is Trump trolling the White House press corps?', The New Yorker (20 March 2017).
} 
arguments', and he insists that the weapon of critique has been 'smuggled through a fuzzy border to the wrong party'. ${ }^{53}$ Not only Latour, but also other critical scholars assume that their own theoretical assumptions, their own tools for dismantling naturalised facts, have become popularised and vulgarised. ${ }^{54}$ Indeed, the sudden popularity of the term post-truth seems to suggest that we are experiencing an entirely new and unheard-of phenomenon, and thus can find one explanation in the popularisation of a crudely transformed version of sophisticated critical theory. ${ }^{55}$ This is, however, a misunderstanding. The relativisation of facts through populist and right-wing movements is not a new phenomenon. The developments being discussed today under the heading of 'post-truth' were described with great precision by analysts of ideology in the twentieth century. From their analyses, one can learn something important about the ideological character of post-truth politics that many contemporary observers have failed to recognise.

\section{The twin character of twentieth-century ideologies}

It was Hannah Arendt who realised that the totalitarian ideologies of the twentieth century relied not merely on a proliferation of lies, but on the abolishment of the very boundary between truth and lie. ${ }^{56}$ These ideologies involve, according to Arendt's analysis in The Origins of Totalitarianism, an 'emancipation from reality'. ${ }^{57}$ Nazi ideology did not simply consist in the naturalisation of a struggle between pre-given entities - namely races - over power and world rule, a naturalised belief that serves as an explanation for an extremely diverse range of events, from economic scandals to government decisions. Nazi ideology involved from the beginning a radical questioning of facts, for instance, of who was responsible for the German defeat in the First World War, or of who 'really' governs the countries of the world (elected governments or Jewish conspirators?). Adherents of the Nazi movement prefer to believe the Protocols of the Elders of Zion than what is written in the newspapers or academic books. ${ }^{58}$ In a similar way, some contemporary supporters of Trump may 'emancipate' themselves from reality. They believe blogs such as the Gateway Pundit, even if it is revealed that the blog doesn't report on facts, since they radically doubt the politics of the establishment and feel insecure about their place in society. ${ }^{59}$ The extreme scepticism towards established facts communicated through so-called mainstream channels and the recurrence to a simple explanatory narrative that ascribes diverse happenings to some kind of dark, manipulative enemy are central features of the ideologies of the twentieth century.

What one can learn from Arendt is that naturalisation and relativisation are closely interrelated. Totalitarian movements are movements precisely because they are constantly in motion,

\footnotetext{
${ }^{53}$ Latour, 'Why has critique run out of steam?', p. 230.

${ }^{54}$ Sergio Sismondo, 'Post-truth?', Social Studies of Science, 47:1 (2017), pp. 3-6; Steve Fuller, 'Is STS all talk and no walk?', EASST Review, 36:1 (2017), pp. 21-2. For refutations of this assumption, see Rhys Crilley and Precious Chatterje-Doody, 'Security studies in the age of "post-truth" politics: In defence of poststructuralism', Critical Studies on Security, 7:2 (2019), pp. 166-70; Aaron Hanlon, 'Postmodernism didn't cause Trump. It explains him', The Washington Post (30 August 2018).

${ }^{55}$ Lee McIntyre, Post-Truth (Cambridge, MA: The MIT Press, 2018), p. 150; Nicholas Michelsen and Benjamin Tallis, 'Post-truth-telling in international relations', New Perspectives, 26:3 (2018), pp. 8-9; Colin Wight, 'Post-truth, postmodernism and alternative facts', New Perspectives, 26:3 (2018), pp. 25-7; Nicholas Michelsen, 'Publicism, truth-pluralism and the usefulness problem', New Perspectives, 26:3 (2018), p. 125; Benjamin Tallis, 'Editorial: Living in post-truth: Power/ knowledge/ responsibility', New Perspectives, 24:1 (2016), pp. 7-18.

${ }^{56}$ Hannah Arendt, The Origins of Totalitarianism (San Diego: Harvest Books, 1979), p. 474. This is also a definitional feature of what Harry Frankfurt later termed 'bullshit'. Harry Frankfurt, On Bullshit (Princeton: Princeton University Press, 2005).

${ }^{57}$ Ibid., p. 471.

${ }^{58}$ The popularity of this document is extensively discussed for instance by Luc Boltanski, Mysteries and Conspiracies: Detective Stories, Spy Novels, and the Making of Modern Societies (Cambridge: Polity Press, 2014).

${ }^{59}$ Hochschild, Strangers in Their Own Land.
} 
constantly fighting a struggle against specific, naturalised enemies, and, in fighting this struggle, transforming the world to make it fit their own ideological beliefs. The totalitarian struggle is thus a struggle not against specific enemies alone, but against reality itself, against the space we share with others and in which human beings appear in their plurality and difference. Through the totalitarian struggle, this space comes under pressure from two sides: on the one hand, through the naturalisation of the enemy; on the other hand, through the relativisation of all those facts that contradict the logic of the naturalised struggle. People who believed that it was the German army who was responsible for the military defeat in 1918 were declared, by those initiated to Nazi ideology, as just naïve: didn't they know that a 'stab-in-the-back' (Dolchstoß) by leftist groups inside Germany had occurred? This relativisation works in close combination with naturalisation, with the identification of a set of claims that is so closely tied to the identity of the movement that it is entirely immunised from critique. ${ }^{60}$ The totalitarian mindset is highly contradictory, it combines relativisation and naturalisation, but since some deeper feelings of exclusion, injury as well as mechanisms of projection are also at play, ${ }^{61}$ this contradiction doesn't pose a problem for the movement. The contradiction is never really acknowledged. On the contrary, the contradictory combination of these two extremes - radical criticism of naïveté and radically naïve belief - is a core element of totalitarian ideology.

The twin character of totalitarian ideology is rooted in its reliance on a specific, well-known figure of thought that also plays a pivotal role in contemporary post-truth politics. This is the figure of conspiracy theorising. As Arendt puts it, totalitarian propaganda 'always strives to inject a secret meaning into every public, tangible event and to suspect a secret intention behind every public political act'. ${ }^{62}$ According to Arendt, ideological thinking can be recognised in this obsessive, generalised suspicion. Ideological thinking is conspiracy thinking writ large. It provides a 'total explanation' of past, present, and future - an explanation that is always to be found in the secret intentions of some mischievous enemies. ${ }^{63}$ And because the conspiracy-theoretical explanation is total, all contradictory facts are relativised and lose their reality. The attitudes of those who joined the ranks of the totalitarian movements - as well as of those who were susceptible to doing so - exhibit a 'mixture of gullibility and cynicism'. ${ }^{64}$ Contemporary studies of conspiracy theories highlight the same mixture albeit in different terms. Conspiracy theory is a 'hybrid of scepticism and belief. ${ }^{65}$ It combines 'two epistemic vices', namely 'paranoia' and 'naivety'. 66

The blindness of those who fall prey to generalised conspiracy thinking (as distinct from particular conspiracy theories, which may or may not be true) consists not least in the fact that these two thought operations - naturalisation and relativisation - stand in stark, yet entirely unacknowledged, contradiction. It is important to note that this twin ideology is not simply a form of stupidity. More than a sign of lacking intelligence, it is a sign of lacking freedom. The stubbornness with which ideological believers insist against all odds on their 'total explanation' is in reality a strait jacket. It exchanges 'the freedom inherent in man's capacity to think for the strait jacket of logic with which man can force himself almost as violently as he is forced by some outside

\footnotetext{
${ }^{60} \mathrm{On}$ immunisation as an aspect of conspiracy theories, see Mathijs Pelkmans and Rhys Machold, 'Conspiracy theories and their truth trajectories', Focaal - Journal of Global and Historical Anthropology, 59 (2011), p. 69.

${ }^{61}$ Helmut König highlights this point in an in-depth reconstruction of the chapter 'Elements of Antisemitism', in Horkheimer and Adorno's Dialectic of Enlightenment. Helmut König, Elemente des Antisemitismus: Kommentare und Interpretationen zu einem Kapitel der Dialektik der Aufklärung von Max Horkheimer und Theodor W. Adorno (Weilerswist: Velbrück, 2016).

${ }^{62}$ Arendt, The Origins of Totalitarianism, p. 471.

${ }^{63}$ Ibid., p. 470.

${ }^{64}$ Ibid., p. 382.

${ }^{65}$ Stef Aupers, “Trust no one": Modernization, paranoia and conspiracy culture', European Journal of Communication, 27:1 (2012), p. 30.

${ }^{66}$ Pelkmans and Machold, 'Conspiracy theories and their truth trajectories', p. 68.
} 
power'. ${ }^{67}$ Ideological thinking is obsessive. It is marked by the obsession to apply with violent force a specific logic - the logic of the naturalised struggle. The violence is directed against all kinds of seeming enemies, often those who are most innocent - and least threatening. Arendt was puzzled by the arbitrariness with which the identification of the enemies changed in totalitarian states. But ultimately the violence is also directed against the ideological believers themselves, for it is they who force themselves into the straitjacket of their own obsessive thinking. Naïveté and cynicism are signs of this obsession. ${ }^{68}$

Arendt's insight into the twin character of ideological thinking resembles that of early Frankfurt School theorists. The figure of conspiracy theory plays an important role in Max Horkheimer and Theodor W. Adorno's reflections on antisemitism in the Dialectic of Enlightenment. ${ }^{69}$ Also two other prominent figures of the early Frankfurt School, Leo Löwenthal and Erich Fromm, clearly perceived the twin character of twentieth-century ideologies. Löwenthal and Fromm detected Arendt's 'mixture of gullibility and cynicism' in the discourse of authoritarian politicians and in the beliefs of common people who were attracted to their promises. In Prophets of Deceit, Löwenthal examines speeches as well as pamphlets of a certain type of dubious politician, the 'agitator. ${ }^{70}$ Löwenthal's sources are not from Germany, but from the United States in the 1940s. And yet, he finds that one of the core characteristics of 'agitation' is that it combines the allegedly certain knowledge that there is a mischievous and manipulating enemy with the pervasive doubt that nothing can be known with certainty, since conspiracies are to be found behind every political event and even behind seemingly innocent happenings. When one reads Prophets of Deceit, one cannot but think of the ways in which Donald Trump addresses his public today, emphasising the threats posed by enemies such as 'radical Islamic terrorists', while at the same time affirming that politics is a cynical business in which facts are merely the creations of selfish actors. ${ }^{71}$

The tools of agitation correspond to the attitudes of those who are attracted by them. In Erich Fromm's early study Escape from Freedom, the 'combination of cynicism and naiveté is explicitly addressed as 'very typical of the modern individual'. ${ }^{72}$ In Fromm's view, this combination was a sign of the core phenomenon under analysis in his book, a flight from freedom. Instead of making use of the freedom granted to them by the resolution of traditional bonds of authority, many individuals sought to escape their freedom and turned instead to authoritarian ideas. One cause of this development was to be found, according to Fromm, in the intellectual climate of modern liberal societies that discouraged people from thinking for themselves. This climate was characterised by the uncritical acceptance of scientific expertise and by uncritical news reporting that presented one fact after the other instead of analysing them in any depth. 'The result of this kind of influence', Fromm observed, 'is a twofold one: one is a scepticism and cynicism towards everything which is said or printed, while the other is a childish belief in anything that a person is told with authority. ${ }^{73}$ Naïveté and cynicism, respectively, take factual knowledge either too seriously or too lightly. They are products of a society in which a pathological way of

\footnotetext{
${ }^{67}$ Arendt, The Origins of Totalitarianism, p. 470.

${ }^{68}$ Fluck similarly reads conspiracy thinking as an expression of a peculiar form of modern subjectivity marked not least by 'compulsion'. Fluck, 'Theory, “truthers”, and transparency', p. 73.

${ }^{69}$ Max Horkheimer and Theodor W. Adorno, Dialectic of Enlightenment: Philosophical Fragments, trans. Edmund Jephcott (Stanford, CA: Stanford University Press, 2002). For a discussion specifically of their account of antisemitism, see König, Elemente des Antisemitismus; see also Fluck, 'Theory, "truthers", and transparency', pp. 68-9.

${ }^{70}$ Leo Löwenthal and Norbert Guterman, Prophets of Deceit: A Study of the Techniques of the American Agitator (Palo Alto: Pacific Books, 1970 [orig. pub. 1949]).

${ }^{71}$ A student in a seminar I taught at the University of Würzburg used Löwenthal's categories of agitation to analyse Trump's tweets. It worked astonishingly well.

${ }^{72}$ Erich Fromm, Escape from Freedom (New York, NY: Avon Books, 1965 [orig. pub. 1941]), p. 276.

${ }^{73}$ Ibid.
} 
dealing with 'facts' has developed. ${ }^{74}$ They are signs of a society's vulnerability to authoritarian tendencies. They are symptoms of a flight from freedom.

Arendt and early Frankfurt School theorists were well aware that the ideological threat of their time had a twin character. The relativisation of all truth emerged together with naturalised belief in specific facts. These theorists of twentieth-century ideologies highlight a specific figure of thought that combines cynicism and naïvety, the figure of conspiracy theorising, and they interpret the phenomenon as a surrender of the human capacity to think freely and critically. Naïveté and cynicism are signs of a distinctly unemancipated, unfree condition of human consciousness. They are signs of domination, even, as Arendt argues, of total domination. This critical analysis of ideology should make us sceptical concerning the interpretation of post-truth politics that dominates debates today. The cynical attitudes of the inhabitants of Latour's home town, who thought that Latour was gullible because he didn't realise 'that the Mossad and the CIA did it', are in all likelihood not an 'absurd deformation of our own [critical] arguments' ${ }^{75}$ They do not stem from the smuggling of tools of critical analysis 'through a fuzzy border to the wrong party'. ${ }^{76}$ Hence, they do not indicate that critique has run 'out of steam'. On the contrary, what these cynical attitudes suggest is that the critical analysis of ideology needs to be reinvigorated.

\section{The task of critique in times of post-truth politics}

In the past decades, many scholars have approached the task of 'ideology critique' with hesitation at best. Apart from the largely implicit and concealed sense of a distinction between right and wrong knowledge claims, as I have reconstructed it in the first two sections of this article, the analysis of 'objectively necessary and yet false consciousness', as Theodor Adorno famously defined the term, had 'fallen into disrepute'. ${ }^{77}$ Maeve Cooke pinpoints the problem that many scholars had with this idea when she writes that Adorno's definition seems 'to deny the capacity of human subjects to act in their own rational interests'. ${ }^{78}$ To ascribe to some people a false consciousness means to treat them in an 'epistemologically authoritarian' way, since it reserves 'knowledge of what counts as a rational interest to the epistemically privileged theorist'. ${ }^{79}$ Indeed, Cooke's charge without doubt applies to Arendt and the early Frankfurt School theorists. They claimed to know better than the objects of their analysis - modern individuals or members of totalitarian movements - the latter's own rational interests and the flaws in their thinking. And yet, in recent years the critical analysis of ideology has experienced something of a revival. ${ }^{80}$ More

\footnotetext{
${ }^{74}$ Also contemporary observers have described a society driven by a desire for 'false clarity' and by the 'commodification of facts' as a prerequisite for the spread of conspiracy thinking and post-truth politics. Fluck, 'Theory, "truthers", and transparency', pp. 68-73; Luca Mavelli, 'Neoliberalism as religion: Sacralization of the market and post-truth politics', International Political Sociology, Online First (2019), p. 13.

${ }^{75}$ Latour, 'Why has critique run out of steam?', pp. 228, 230.

${ }^{76}$ Ibid., p. 230.

${ }^{77}$ Theodor W. Adorno, 'Beitrag zur Ideologienlehre', Soziologische Schriften I (Frankfurt am Main: Suhrkamp, 1972), p. 465; Maeve Cooke, 'Resurrecting the rationality of ideology critique: Reflections on Laclau on ideology', Constellations, 13:1 (2006), p. 4; Rahel Jaeggi, 'Rethinking ideology', in B. de Bruin and C. F. Zurn (eds), New Waves in Political Philosophy (Basingstoke: Palgrave Macmillan, 2009), p. 63.

${ }^{78}$ Cooke, 'Resurrecting the rationality of ideology critique', p. 4.

${ }^{79}$ Ibid. See also Geuss (The Idea of a Critical Theory) on this point. Also Niklas Luhmann advanced a similar critique. Florian Edelmann, “I see something you don't see": Niklas Luhmann's social theory between observation and meta-critique', in Benjamin Martill and Sebastian Schindler (eds), Theory as Ideology in International Relations: The Politics of Knowledge (London: Routledge, forthcoming 2020). And long before these thinkers, Karl Mannheim realised that the pejorative connotation of the term led to a situation in which it was predominantly used as an allegation directed against one's adversaries. On this point, see Beate Jahn, 'Liberal internationalism: From ideology to empirical theory - and back again', International Theory, 1:3 (2009), pp. 409-38; Benjamin Herborth, 'Ideology as decontestation', in Martill and Schindler (eds), Theory as Ideology in International Relations.

${ }^{80}$ Kristina Lepold, 'An ideology critique of recognition: Judith Butler in the context of the contemporary debate on recognition', Constellations, 25:3 (2018), pp. 474-84; Benjamin Martill, 'International ideologies: Paradigms of ideological
} 
generally, Arendt and early critical theorists have become increasingly important sources of reference. A variety of scholars have sought to revive the critical thinking of theorists such as Marx, Adorno, Horkheimer, Fromm, and Arendt. ${ }^{81}$ In my view, this revival is a result not least of the insight that the problem Cooke identified with Adorno's concept of ideology - epistemological authoritarianism - need not prevent us from taking a clear stance towards the increasingly obvious crisis of our time. Taking a clear stance requires that we make a clear and explicit (unconcealed) distinction between truth and falsehood, between theory and ideology. Indeed, I would say that the flaw in Cooke's own perspective is that making such a distinction does not necessarily express disrespect for the holders of the criticised beliefs or treat them in an authoritarian manner. On the contrary, if I am convinced that someone else's beliefs are delusional and false, the best way to express my respect for that person is to say openly and clearly what I think the problem is with these beliefs. And precisely this is the task of critique when it comes to confronting the challenge of post-truth.

The hesitation to say what is false about the beliefs of other people is understandable. In a time of relativising critique, the very idea of a measure that allows to distinguish between right and false knowledge is discredited. ${ }^{82}$ Such a measure presupposes a kind of knowledge that is not merely subjective and relative to one's own perspective. It presupposes a transcendent viewpoint from which one can relate two perspectives to each other, one's own and another one's. Yet access to this viewpoint, which Cox described as a 'perspective on perspectives', does not require that we leave behind all reflexive awareness. ${ }^{83}$ A perspective on perspectives can be achieved precisely through the serious and critical engagement with other perspectives. Such a perspective is neither entirely dissociated from any standpoint in time and space, nor entirely resolved only in one. It is neither entirely objective nor purely subjective.

It may seem that the crucial characteristic of a 'perspective on perspectives' is that it is intersubjective. It has brought two perspectives into conversation, and thereby made it possible to transcend one's own initial perspective. In a certain sense this is true. Yet in the specific case of ideology critique, it is not necessary that the criticised perspective be overcome through intersubjective dialogue. This may very well be a wished-for and hoped-for outcome of such critique, but it is not its main point. The main point is that a critique of ideology allows us to make our

analysis and world politics', Journal of Political Ideologies, 22:3 (2017), pp. 236-55; Albena Azmanova, 'The costs of the democratic turn in political theory', in Martill and Schindler (eds), Theory as Ideology in International Relations; Jaeggi, 'Rethinking ideology'.

${ }^{81}$ On Marx, see Koddenbrock, 'Strategies of critique in IR; Schmid, 'The poverty of critical theory in International Relations'. On Adorno, see Jaeggi, 'Rethinking ideology'; Fluck, 'Truth, values and the value of truth in critical International Relations theory'; Fluck, 'The best there is?'; Daniel J. Levine, Recovering International Relations: The Promise of Sustainable Critique (Oxford: Oxford University Press, 2012). On Horkheimer, see Beate Jahn, 'Brexit, Trump and the Responsibilities of Critical International Relations Theory', paper presented at EISA Workshop Theory as Ideology, Cardiff, UK, 2017. On Fromm, see Azmanova, 'Crisis?'; Ben Christian, 'Die Flucht ins Postfaktische: Von der Selbst-Verleugnung zur Welt-Verleugnung', Soziologie Magazin (2019). On Arendt, see Christian Volk, 'Towards a critical theory of the political: Hannah Arendt on power and critique', Philosophy and Social Criticism, 42:6 (2016), pp. 549-75; Felix Rösch, 'Realism as social criticism: The thinking partnership of Hannah Arendt and Hans Morgenthau', International Politics, 50:6 (2013), pp. 815-29; Hartmut Behr, 'Theory vs. ideology: Validity criteria for knowledge claims and normative conditions of critique', in Martill and Schindler (eds), Theory as Ideology in International Relations; Hartmut Behr, 'Conditions of critique and the non-irreversibility of politics', Journal of International Political Theory, 13:1 (2017), pp. 122-40. For a combined discussion of how Fromm, Horkheimer, Adorno, as well as Simone Weil and Norbert Eilas, can illuminate the current predicament, see Andrew Linklater, 'Towards a sociology of global morals with an "emancipatory intent", Review of International Studies, 33:S1 (2007), pp. 135-50.

${ }^{82}$ One interesting example of this can be found in Tim Aistrope and Roland Bleiker's otherwise intriguing treatment of conspiracy theories. Aistrope and Bleiker rightly challenge the orientalism inherent in the idea that only Arab Muslims have conspiracy theories; yet their own theoretical approach in the end leaves no means at all to distinguish between right and false conspiracy allegations, whether in Western or non-Western discourse. Tim Aistrope and Roland Bleiker, 'Conspiracy and foreign policy', Security Dialogue, 49:3 (2018), pp. 165-82.

${ }^{83} \mathrm{Cox}$, 'Social forces, states and world orders', p. 128. 
own knowledge of society more objective. It improves our own understanding of the problems of the society we live in. It can have this effect because the ideology's flaws contain a kernel of truth, a kernel we can bring to the fore and uncover by means of critique. An ideology is never merely false - it is, to quote Adorno's formula once again, also 'objectively necessary'. ${ }^{84}$ As Rahel Jaeggi puts it, an ideology is both false and true at the same time. ${ }^{85}$ Yet the truth of an ideology is not of a direct, epistemological kind, in the sense that its claims deliver a true depiction of the reality of a society. Its truth is more of an indirect, psychological, and emotional kind. ${ }^{86}$ It is a truth about society that needs to be discerned and revealed in claims that are obviously and evidently false claims like those made by Trump, Conway, and Hoft.

In order to bring to the fore the kernel of truth - that is, in order to understand what the present tendency towards post-truth conspiracy thinking tells us about our time - it is crucial to come to grips with the epistemological flaw of this ideology. Post-truth politics is a flawed way of dealing with truth. Crucially, its flaw is that it is unbalanced in two opposite senses. On the one hand (and this is what has led to the coining of the term 'post-truth'), it relativises all truth. It claims that there is no objective truth, only subjective perspectives. But on the other hand, it also unconsciously and unknowingly advances a specific truth claim: a claim to know 'the' truth about the nature of the world. This alleged 'truth' is the idea that everything is manipulated, that public appearances are nothing but the product of hidden interests and disguised quests for power. The contradictory combination of cynical disbelief and naïve belief, which worried students of twentieth-century ideologies so much, can actually be detected in all three episodes of post-truth politics discussed above. Trump's tweet relativises one fact (climate change) and it naturalises another (the 'fact' of the Chinese invention of it). Equally Conway's term 'alternative facts' relativises one fact (the number of people attending Trump's inauguration) and it naturalises another (the 'fact' that photographic evidence is manipulated and therefore has alternatives). Finally, also Hoft's laughter relativises one fact (the fact-checking undertaken by The New Yorker) and it naturalises another (the 'fact' that media reporting is an entirely cynical business). In all three cases, relativisation is combined with naturalisation. And in all three cases, this peculiar combination is the product of the conspiracy-theoretical assumption that the facts we possess about public events, and even the practice of checking those facts, are worth nothing since in truth some kind of secret intention is behind them. Like totalitarian ideology, post-truth politics is conspiracy thinking writ large.

The similarity of post-truth politics and totalitarian ideology provides grounds for concern. It does not mean that we are reliving precisely the same historical moment. ${ }^{87}$ History doesn't repeat itself, as Marx famously quipped, except as a farce. Yet the similar basic nature of the ideology

\footnotetext{
${ }^{84}$ Adorno, 'Beitrag zur Ideologienlehre', p. 465.

${ }^{85}$ Jaeggi, 'Rethinking ideology'. See also Fluck, 'Theory, “truthers”, and transparency', who makes this point specifically for conspiracy theories.

${ }^{86}$ It is therefore no surprise that, as Andrew Linklater has stressed, 'Frankfurt School critical theory - and related perspectives in the interwar period - moved the psychological and emotional features of human existence to the forefront of sociological analysis.' Linklater quotes specifically Adorno to the effect that 'the critical study of society has a responsibility to "lend a voice to suffering"', and adds that this is in fact 'a condition of all truth'. Linklater, 'Towards a sociology of global morals with an "emancipatory intent", pp. 142-3. Post-truth is, in this sense, the expression of suppressed suffering. The standard definition of post-truth (according to which emotions and 'felt' truth replace rational truth) captures this quite well - only that there is indeed a real and serious 'felt truth' to uncover. Note that Robin Celikates's account of 'critique as social practice' also moves in the direction indicated here. Celikates suggests returning to the early psychological roots of critical theory in order to analyse contemporary blockages of actors' capacities for thinking critically. Post-truth represents precisely such a blockage. Robin Celikates, Critique as Social Practice: Critical Theory and Social Self-Understanding (Lanham: Rowman \& Littlefield, 2018).

${ }^{87}$ There are doubtless important differences. I would, however, disagree with Ari-Elmeri Hyvönen's claim that the logical stringency of ideological thinking 'often seems lacking in the case of post-truth politics'. Ari-Elmeri Hyvönen, 'Careless speech: Conceptualizing post-truth politics', New Perspectives, 26:3 (2018), p. 41. The obsession with which ulterior interests are today suspected behind public events is a marker precisely of the logical stringency of excessive conspiracy thinking.
} 
does mean that the problem of post-truth needs to be taken very seriously. Post-truth politics may very well have more dire effects than the ones palpable until now if it is not recognised for what it is. We must therefore attempt to come to grips precisely with what is flawed. These two claims that there is no truth at all and that there is only one truth - are flawed in a similar manner. They are akin to what Heikki Patomäki and ColinWight have described as the twin mistakes of positivism and post-positivism: 'naïve belief in a "world out there" and 'making the world "all in here"' ${ }^{88}$ The first (naïveté) dissolves the subject in the world; the second (cynicism) dissolves the world in the subject. The flaw they both share is thus that they do not conceive of subject and object as independent from each other. There is no dialectic of subject and object, no dynamic relationship between self and world, no co-constitution of agent and structure. ${ }^{89}$ There is either only the subjective, or only the objective. This is the core flaw of post-truth. This is what makes it ideological.

The flaw is indicative of a deeper problem. It indicates that we live in a time when many human beings cannot realise their capacity to relate in an independent, reflexive manner to the world. Something is disrupting the possibility of what Fluck terms 'subject-object communication'. ${ }^{90}$ Something is driving people away from confronting the difficulty of relating to a world they do not fully control. Something is driving them to seek refuge instead in the easy twin answers that there is either no truth at all or only one simple truth. It is not unlikely that this 'escape from freedom' has its origins in the overwhelming pressures of conformity that exist in a society of unleashed competition. ${ }^{91}$ These pressures throw people back onto themselves and make them concerned exclusively about their own egoistic worries - and at the same time, they give them the feeling of being victimised objects who have no one in the world who really listens

\footnotetext{
${ }^{88}$ Heikki Patomäki and Colin Wight, 'After post-positivism? The promises of critical realism', International Studies Quarterly, 44:2 (2000), p. 215.

${ }^{89}$ The insight into the continuous dynamic of subject-object relations is foundational of the thought of a number of prominent critical theorists - and arguably of critique itself. In the words of Fluck, who here paraphrases Adorno, 'subject and object "mediate" each other; human reason is shaped by objective conditions but, at the same time, we cannot understand objective conditions other than as they are mediated through our current understanding'. Fluck, 'The best there is?', p. 67. This idea features for instance in Kant's critique of pure reason and specifically his core idea that all knowledge has two roots, intellectual categories and sensual experience. Immanuel Kant, Critique of Pure Reason (Cambridge: Cambridge University Press, 1998). It also marks Wendt's account of the agent-structure problem and specifically the claim that agents and structures are 'mutually constitutive yet ontologically distinct entities'. Alexander Wendt, 'The agent-structure problem in International Relations theory', International Organization, 41:3 (1987), p. 360. It is at the heart of the critical-theoretical notion of dialectical thinking that provides insight into the 'changes and continuities we author collectively and are simultaneously exposed to'. Christian Heine and Benno Teschke, 'Sleeping Beauty and the dialectical awakening: On the potential of dialectic for International Relations', Millennium, 25:2 (1996), p. 400. It means that, in research practice, we need to be continually aware of the choice between understanding the subjective and approaching the objective - between 'getting close' and 'gaining distance'. Sebastian Schindler and Tobias Wille, 'How can we criticize international practices?', International Studies Quarterly, 63:4 (2019), pp. 1014-24. However, it is not the case that subject and object are necessarily in tension or contradiction. All that is required here is the acknowledgement that there is a continuous dynamic of contradiction and reconciliation. The challenge for us as beings capable of reflexive, critical thought is to come to terms time and again with establishing a relationship between us and the world, between subjective and objective. Our specific condition is that this task can be achieved only because we are not alone in the world but find ourselves confronted with a plurality of perspectives. It was Immanuel Kant who once exclaimed: 'Yet how much and how correctly would we think if we did not think as it were in community with others ... !' Immanuel Kant, 'What does it mean to orient oneself in thinking', in Kant, Religion and Rational Theology, ed. and trans. Allen Wood and George di Giovanni (Cambridge: Cambridge University Press, 1996), pp. 1-18 (p. 16). The critique of ideology is one specific way of materialising the potential inherent in this condition.

${ }^{90}$ Fluck, 'The best there is?', p. 67.

${ }^{91}$ Fromm, Escape from Freedom. The stronger these pressures, the stronger the anxiety about one's status in society. The link between status anxiety and the spread of conspiracy thinking is explored by Richard Hofstadter, The Paranoid Style and Other Essays (Cambridge: Harvard University Press, 1964), pp. 82-6. For more recent contributions that examine the more general link between market pressures and post-truth, see Mats Hyvönen, 'As a matter of fact: Journalism and scholarship in the post-truth era', in Michael Peters, Sharon Rider, Mats Hyvönen, and Tina Besley (eds), Post-Truth, Fake News: Viral Modernity \& Higher Education (Singapore: Springer, 2018), pp. 124-5; Mavelli, 'Neoliberalism as religion'.
} 
to them and supports them. ${ }^{92}$ Crucially, these pressures make people fearful of the very thing that could actually help them out - namely collective action, taking responsibility for collective affairs, the readiness to fight for collective rather than selfish goals. ${ }^{93}$ The task of critique is to identify these pressures and to point us in the direction of a society in which people are capable of taking their own stance in the world rather than giving in and giving up. This is, again in Fluck's terms, a society 'where human subjects stand in a non-instrumental relationship to the objectivity of which they are a part'. ${ }^{94}$ Put in a less sophisticated way, it is a society in which people have the courage to voice their own views on worldly matters and are not afraid of being refuted or disproven. It is a society that values collective action instead of assuming that all action is motivated by egoistic interests.

\section{Conclusion}

In this article, I have sought to establish greater clarity about a phenomenon that many observers have termed 'post-truth politics'. I have inquired into the implications of this phenomenon for contemporary critical thinking. There is a widespread tendency today - of which critical IR provides one example - to associate critique exclusively with reflexivity, that is, with awareness of the historicity and constructed character of knowledge. This tendency is founded on a binary distinction (which often remains implicit) according to which ideologies naturalise knowledge, while critical theories relativise it. The naturalisation/relativisation binary creates a peculiar logic of progress that drives critical theories in the direction of excessive relativisation. However, as Latour recognised as early as 2004, relativisation constitutes an urgent political problem. In a situation in which scepticism concerning facts has become excessive, relativising critique loses its critical function.

While Latour and many others have a point when they deplore an attitude that exclusively relativises knowledge, they are wrong when they assume that critique is responsible for the present crisis - that, to quote Latour's key sentence one more time, the weapon of critique has been 'smuggled through a fuzzy border to the wrong party'. ${ }^{95}$ The falsity of this widespread conclusion becomes apparent when one engages with studies of twentieth-century ideologies, which have clearly demonstrated that there is a peculiar form of ideology that combines naturalisation and relativisation in a contradictory way - an ideological attitude that uncritically accepts certain facts (notably the 'fact' that there are conspiracies everywhere) while at the same time uncritically rejecting all others. This mixture of naïveté and cynicism, which is a feature of excessive conspiracy theorising, was not only a mark of the ideologies of the twentieth century, but is also characteristic of present-day post-truth politics.

The task of critique is to confront and counter this resurgent ideology. To accomplish this task, it is necessary to grasp with great clarity the flaw of this ideology, which resides in the fact that it

\footnotetext{
${ }^{92}$ The words that he speaks for those who feel 'unheard' run like a refrain through Trump's speeches. Trump epitomises a mixture many people seem to identify with today, a mixture of reckless egoism with the posture of an innocent victim - a mixture that Arendt recognised in the two principal personalities that indicate the crisis of our time, criminal and saint. Hannah Arendt, The Human Condition (Chicago: University of Chicago Press, 1958), p. 180. The posture of victimisation is a core feature of earlier and contemporary forms of fascist ideology. Maik Fielitz and Holger Marcks, 'Digital Fascism: Challenges for the Open Society in Times of Social Media', Berkeley Center for Right-Wing Studies Working Paper Series (16 July 2019), pp. 5-8.

${ }^{93} \mathrm{~A}$ society of unleashed competition is marked, despite an enormous amount of online communication, by feelings of fear, loneliness, and isolation. Zygmunt Bauman, Strangers at Our Doors (Cambridge: Polity Press, 2016). It is, in Azmanova's terms, one of 'political economy of fear'. Albena Azmanova, 'Against the politics of fear: On deliberation, inclusion, and the political economy of trust', Philosophy and Social Criticism, 37:4 (2011), pp. 401-12. Loneliness and isolation are sometimes mistaken for the solitude that we all need and require, but they are in reality highly worrisome products of a distinctly modern, Western, and capitalist condition. Arendt, The Origins of Totalitarianism, pp. 476-8.

${ }^{94}$ Fluck, 'The best there is?', p. 77; Matthew Fluck, The Concept of Truth in International Relations Theory: Critical Thought Beyond Post-Positivism (Basingstoke: Palgrave Macmillan, 2017), p. 230.

${ }^{95}$ Latour, 'Why has critique run out of steam?', p. 230.
} 
is excessive in two opposite senses. It lacks a balance between the subjective and the objective, between the self and the world, between agent and structure, and instead resolves the relationship between subject and object in one or the other direction, uncritically accepting a certain 'objective truth' about the world (the existence of conspiracies everywhere) while at the same time uncritically rejecting any claim to objectivity (since there are 'only' perspectives). This flaw points to the deeper truth that today individuals are subject to strong pressures of conformity that prevent them from finding their own independent role in a world they do not fully control. Emancipating ourselves from these pressures requires above all recovering our sense for collective action, that is, the capacity to stand up for our own convictions in the face of objective difficulties and subjective differences.

Acknowledgments. For helpful comments on earlier drafts of this article, I am grateful to Audrey Alejandro, Felix Anderl, Hartmut Behr, Felix Biermann, Lisa Bogerts, Jennifer Brichzin, Ben Christian, Christopher Daase, Raymond Duvall, Alejandro Esguerra, Gordon Finlayson, Matthew Fluck, Stefano Guzzini, Michael Hamilton, Rainer Hülsse, Kimberly Hutchings, Beate Jahn, Victor Kempf, Friedrich Kratochwil, Stefan Kroll, Christopher Long, Holger Marcks, Benjamin Martill, Louiza Odysseos, Nicholas Onuf, Berthold Rittberger, Justin Rosenberg, Johanna Speyer, Jens Steffek, Benno Teschke, Lora Viola, Valerie Waldow, Philip Wallmeier, Moritz Weiss, Tobias Wille, Bernhard Zangl, and two anonymous reviewers. I also thank Ciaran Cronin for editing the final version.

Sebastian Schindler is Assistant Professor at the Geschwister Scholl Institute of Political Science, Ludwig-MaximiliansUniversität München, Germany.

Cite this article: Schindler, S. 2020. The task of critique in times of post-truth politics. Review of International Studies $\mathbf{4 6}$, 376-394. https://doi.org/10.1017/S0260210520000091 